\title{
Jurist-Diction
}

Volume 4 No. 5, September 2021

\section{Perlindungan Hukum Bagi Pelaku Usaha Terhadap Pencabutan Izin Reklamasi oleh Pemerintah Daerah}

\author{
Inigo Putera Bagus Juwono \\ inigopbj12@gmail.com \\ Universitas Airlangga
}

\begin{abstract}
How to cite:
Inigo Putera Bagus Juwono, 'Perlindungan Hukum Bagi Pelaku Usaha Terhadap Pencabutan Izin Reklamasi oleh Pemerintah Daerah' (2021) Vol. 4 No. 5 JuristDiction.
\end{abstract}

Histori artikel:

Submit 11 Juli 2021;

Diterima 15 Agustus 2021;

Diterbitkan 1 September 2021.

DOI:

10.20473/jd.v4i5.29818

p-ISSN: 2721-8392

e-ISSN: $2655-8297$

\section{Abstract}

Availability lands in Indonesia doesn't get along with growth citizen in Indonesia. The government is giving a solution to the building of the reclamation, but under the construction of the reclamation always inflict variety of problems. Permission cancellation for reclamation is action legal by government in order to annulment permission for its reclamation, government should pay attention in aspect of: authority, procedure and substantion. Besides, annulment permission reclamation by government based on legislation and principle general a good government. A legal form of legal protection by receiving authorization of reclamation In this case, the businessman or developers do administrative efforts and filing suit to civil court of justice. If there are parties that are affected with the verdict, can file an appeal to civil court of justice, it can be even comitted cassation law to supreme court of Indonesia.

Keywords: Reclamation; Permission; Cancellation.

\begin{abstract}
Abstrak
Ketersediaan lahan di Indonesia tidak sejalan dengan pertumbuhan penduduk yang semakin meningkat. Pemerintah memberikan solusi dengan pembangunan pulau reklamasi, akan tetapi dalam pembangunan pulau reklamasi tersebut kerap kali menimbulkan berbagai macam permasalahan. Pencabutan izin pulau reklamasi merupakan salah bentuk tindakan hukum yang dapat dilakukan oleh pemerintah. Dalam pencabutan izin reklamasi tersebut, pemerintah hendaknya memperhatikan keabsahan pemerintah dalam aspek wewenang, aspek prosedur dan aspek substansi. Selain itu, pencabutan izin reklamasi oleh pemerintah wajib berdasarkan peraturan perundang-undangan dan Asas Umum Pemerintahan yang Baik. Bentuk perlindungan hukum yang dapat dilakukan oleh penerima izin reklamasi dalam hal ini pelaku usaha ataupun pengembang dengan melakukan upaya administratif dan mengajukan gugatan ke Pengadilan Tata Usaha Negara. Apabila ada pihak yang merasa dirugikan dengan putusan tersebut, dapat mengajukan banding ke Pengadilan Tinggi Tata Usaha Negara, bahkan dapat dilakukan upaya hukum kasasi kepada Mahkamah Agung.

Kata Kunci: Reklamasi; Izin; Pencabutan.
\end{abstract}

Copyright (C) 2021 Inigo Putera Bagus Juwono 


\section{Pendahuluan}

Perubahan merupakan suatu proses menuju peningkatan taraf hidup manusia tidakterlepas dariaktivitas pemanfaatan sumber daya alam, pembangunan merupakan salah satu proses meunuju perubahan tersebut. Seiring dengan pembangunan yang terus berlangsung, terlebih di Indonesia dengan jumlah penduduk mencapai lebih dari 200 juta jiwa ini membawa dampak yang sangat kompleks terhadap berbagai aspek kehidupan masyarakatnya. Ruang wilayah Negara Kesatuan Republik Indonesia, baik sebagai kesatuan wadah yang meliputi ruang darat, ruang laut dan ruang udara. Segala yang termasuk ruang di dalam bumi maupun sebagai sumber daya merupakan karunia Tuhan Yang Maha Esa kepada bangsa Indonesia yang perlu disyukuri, dilindungi dan dikelola secara berkelanjutan untuk sebesar-besarnya kemakmuran rakyat yang sesuai dengan amanat yang terkandung di dalam Pasal 33 ayat 3 Undang-Undang Dasar Negara Republik Indonesia Tahun 1945. ${ }^{1}$

Ketersediaan lahan tersebut tidak sejalan dengan pembangunan yang terus dilakukan oleh pemerintah, baik pembangunan yang dilakukan oleh Pemerintah Pusat maupun Pemerintah Daerah di beberapa wilayah Indonesia. Ketidakseimbangan antara pembangunan yang terus dilakukan dengan luas tanah yang tersedia serta kebutuhan penggunaan yang semakin meningkat mengakibatkan tanah memiliki arti yang sangat penting bagi masyarakat Indonesia, campur tangan pemerintah merupakan suatu hal yang mutlak. Pemerintah sendiri sudah menemukan salah satu solusi alternatif dari pemecahan masalah tersebut, yakni salah satu solusi tersebut dengan melakukan reklamasi. Reklamasi merupakan suatu pekerjaan atau usaha memanfaatkan kawasan atau lahan yang relatif tidak berguna atau masih kosong dan berair menjadi lahan yang berguna dengan cara dikeringkan. ${ }^{2}$ Pengertian reklamasi menurut Pasal 1 angka 23 Undang-Undang Nomor 1 Tahun 2014 tentang Pengelolaan Wilayah Pesisir dan Pulau-pulau kecil, yakni: "Kegiatan yang dilakukan oleh orang dalam rangka meningkatkan manfaat sumber daya lahan ditinjau dari

\footnotetext{
${ }^{1}$ Urip Santoso, Hukum Penataan Ruang (Airlangga University Press Surabaya 2012).[1].

${ }^{2}$ Antik Bintari dan Talolo Muara, 'Manajemen Konflik Penyelesaian Kasus Reklamasi Pulau G Pantai Utara Jakarta' (2018) 41 Jurnal Ilmu Pemerintah.[119].
} 
sudut lingkungan dan sosial ekonomi dengan cara pengurugan, pengeriangan lahan atau drainase". Dalam pembangunannya reklamasi mengalami berbagai macam pro dan kontra, serta dampak positif dan negatif dari berbagai aspek yang ditumbulkan dari adanya reklamasi ini. Sumber daya alam merupakan salah satu modal dasar dalam pembangunan nasional, oleh karena itu harus dimanfaatkan sebesar-besarnya untuk kepentingan rakyat dengan memperhatikan kelestarian hidup sekitar. ${ }^{3}$

Berdasarkan Pasal 12 Peraturan Pemerintah Nomor 16 Tahun 2004 tentang Penatagunaan tanah, dinyatakan bahwa tanah yang berasal tanah timbul atau hasil reklamasi di wilayah-wilayah perairan pantai, pasang surut, rawa, danau dan bekas sungai dikuasai langsung oleh Negara. Selanjutnya dalam Penjelasan Pasal 12 Peraturan Pemerintah Nomor 16 Tahun 2004 dinyatakan bahwa tanah timbul adalah daratan yang terbentuk secara alami maupun buatan karena proses pengendapan sungai, danau, pantai dan pulau timbul, serta penguasaannya dikuasai oleh Negara. Untuk mendapatkan hak atas tanah, pelaku usaha ataupun pengembang mengajukan permohonan pemberian hak atas tanah kepada Kepala Badan Pertanahan Nasional Republik Indonesia. Hak atas tanah yang dapat diajukan oleh pelaku usaha ataupun pengembang tersebut adalah Hak Guna Bangunan atau Hak Pakai.

Reklamasi merupakan proyek besar pengembangan perkotaan, kegiatan reklamasi ini dapat dilaksanakan apabila manfaat sosial dan ekonomi yang diperoleh dari pembangunan reklamasi tersebut lebih besar dari aspek sosial dan aspek ekonominya. Beberapa wilayah di Indonesia sendiri sudah melaksanakan proyek reklamasi, contohnya seperti Reklamasi Teluk Benoa, Reklamasi di Kepulauan Riau serta Reklamasi Teluk Jakarta. Beberapa proyek reklamasi yang dilakukan di Indonesia kerap kali mengalami berbagai macam permasalahan, mulai dalam proses pembangunannya yang tidak sesuai dengan prosedur hingga kasus suap kepada para pejabat daerah tersebut terhadap penerbitan izin reklamasi. Proyek reklamasi yang beberapa tahun terakhir kerap kali disorot media karena pembangunannya sampai saat ini masih menjadi perdebatan yakni proyek pembangunan Reklamasi Teluk

\footnotetext{
${ }^{3}$ Erwin, Hukum Lingkungan (Refika Aditama Bandung 2008).[47].
} 
Jakarta. Izin Pulau Reklamasi Teluk Jakarta sendiri telah diterbitkan pada tahun 1995 oleh Presiden Soeharto dengan menetapkan Keputusan Presiden Nomor 52 Tahun 1995 tentang Reklamasi Pantai Utara Jakarta. Pembangunan proyek Reklamasi Teluk Jakarta ini tidak kunjung usai, walaupun dalam pembangunannya setidaknya telah dibangun 4 pulau reklamasi dari 17 pulau yang direncanakan. Dalam proyek ini permasalah perizinan yang menjadi masalah dalam proses pembangunanya. Gubernur DKI Jakarta Anies Baswedan resmi mencabut semua izin terkait reklamasi teluk Jakarta, pencabutan dilakukan setelah Badan Koordinasi Pengelolaan Reklamasi Pantai Utara Jakarta melakukan verifikasi terkait semua izin di 13 pulau buatan itu. ${ }^{4}$ Anies Baswedan selaku Gubernur DKI Jakarta mencabut 13 izin pulau reklamasi dari 17 pulau, 3 pulau yang dicabut izinnya tersebut dituangkan dalam Keputusan Gubernur Provinsi Daerah Khusus Ibukota Jakarta Nomor 1409 Tahun 2018 tentang Pencabutan Beberapa Keputusan Gubernur Tentang Pemberian Izin Pelaksanaan Reklamasi. Dari permasalahan yang terjadi terkait pencabutan izin reklamasi yang dilakukan oleh Gubernur DKI Jakarta Anies Baswedan tentunya menjadi sesuatu hal yang menarik untuk dibahas lebih lanjut terhadap keabsahan dari pencabutan izin reklamasi tersebut, serta perlindungan hukum yang dapat dilakukan oleh para pelaku usaha ataupun pengembang terhadap pencabutan izin tersebut. Berdasarkan hal tersebut, maka rumusan masalah dalam penelitian ini adalah:

1. Keabsahan Pemerintah Daerah dalam pencabutan izin reklamasi.

2. Upaya perlindungan hukum yang dapat dilakukan oleh pengembang atau pelaku usaha terhadap pencabutan izin reklamasi.

Tulisan ini menggunakan pendekatan peraturan perundang-undangan (statute approach), pendekatan konseptual (conceptual approach) dan pendekatan kasus (case approach). Pendekatan perundang-undangan dilakukan dengan menelaah semua peraturan perundang-undangan yang bersangkutan, untuk pendekatan konseptual beranjak dari pandangan-pandangan dan doktrin yang berkembang di

\footnotetext{
4 'Anies Baswedan Resmi Cabut Izin Reklamasi Teluk Jakarta', <https://metro.tempo. $\mathrm{co} / \mathrm{read} / 1130345 /$ anies-baswedan-resmi-cabut-izin-reklamasi-teluk-jakarta/full\&view=ok $>, 26$ September 2018, dikunjungi pada 14 Oktober 2019.
} 
dalam ilmu hukum. Sedangkan Pendekatan kasus dilakukan dengan cara melakukan telaah terhadap kasus-kasus yang berkaitan dengan isu yang telah dihadapi yang telah menjadi putusan pengadilan yang telah mempunyai kekuatan yang tetap. ${ }^{5}$

\section{Keabsahan Pemerintah dalam Pencabutan Izin Reklamasi}

Keputusan administrasi negara merupakan tindakan hukum sepihak oleh pemerintah yang kewenangannya diberikan kepada jabatan yang ada di dalamnya, dan dilaksanakan secara senyatanya oleh pejabatnya berdasarkan ketentuan hukum positif yang sifatnya konkrit, individual, dan final. ${ }^{6}$ Keputusan tersebut dibuat untuk menertibkan setiap tindak laku masyarakat yang diatur dalam peraturan perundangundangan, sehingga dalam mengeluarkan keputusan tersebut memiliki dasar hukum yang kuat. Berdasarkan Pasal 1 angka 9 Undang-Undang Nomor 51 Tahun 2009 tentang Perubahan Kedua Atas Undang-Undang Nomor 5 Tahun 1986 tentang Peradilan Tata Usaha Negara (selanjutnya disebut dengan UU PTUN) merumuskan bahwasanya "Keputusan Tata Usaha Negara adalah suatu penetapan tertulis yang dikeluarkan oleh badan atau pejabat tata usaha negara yang berisi tindakan hukum tata usaha negara yang berdasarkan peraturan perundang-undangan yang berlaku, yang bersifat konkret, individual, dan final, yang menimbulkan akibat hukum bagi seseorang atau badan hukum perdata".

Berdasarkan pengertian Keputusan Tata Usaha Negara sebagaimana terdapat dalam Pasal 1 angka 9 UU PTUN, pengertian Keputusan Tata Usaha Negara tersebut apabila diuraikan akan ditemukan unsur-unsurnya sebagai berikut: ${ }^{7}$

1. Penetapan tertulis;

2. Dikeluarkan oleh badan atau pejabat tata usaha negara;

3. Berisi tindakan Hukum Tata Usaha Negara berdasarkan peraturan perundangundangan;

4. Bersifat konkret, individual dan final;

5. Menimbulkan akibat hukum bagi seseorang atau badan hukum perdata.

\footnotetext{
${ }^{5}$ ibid.[134].

${ }^{6}$ Herman dan Hendry Julian Noor, 'Doktrin Tindakan Hukum Administrasi Negara Membuat Keputusan (Beschikking)’ (2017) 31 Jurnal Komunikasi Hukum.[94].

${ }^{7}$ R. Wiyono, Hukum Acara Peradilan Tata Usaha Negara (Sinar Grafika Jakarta 2008).[18].
} 
Elemen-elemen tersebut bersifat komulatif, yang artinya untuk dapat memenuhi unsur KTUN yang dapat disengketakan di Pengadilan Tata Usaha Negara maka harus memenuhi seluruh unsur-unsur tersebut. Pengertian Keputusan Tata Usaha Negara atau Keputusan Administrasi Negara yang selanjutnya disebut Keputusan menurut Pasal 1 angka 7 Undang-Undang Nomor 30 Tahun 2014 tentang Administrasi Pemerintahan (selanjutnya disebut dengan UU Administrasi Pemerintahan), yakni: “Keputusan Administrasi Pemerintahan yang juga disebut Keputusan Tata Usaha Negara atau Keputusan Administrasi Negara yang selanjutnya disebut Keputusan adalah ketetapan tertulis yang dikeluarkan oleh Badan dan/atau Pejabat Pemerintahan dalam penyelenggaraan pemerintahan”.

Setiap tindakan yang dilakukan baik oleh Pemerintah Pusat maupun Pemerintah Daerah dalam penetapan suatu keputusan harus berdasarkan atas adanya prinsip legalitas (rechtmatigheid). Prinsip legalitas ini sebagai dasar terpenting dari negara hukum yang mengandung arti bahwa pemerintah hanya dapat melakukan segala tindakan pemerintah berdasarkan kewenangan yang telah diberikan dan dibatasi oleh peraturan perundang-undangan yang berlaku. Philipus M. Hadjon menyatakan bahwa prinsip penyelenggaraan pemerintahan adalah berdasarkan prinsip negara hukum dengan prinsip dasar legalitas (rechtmatigheid van het bestuur). ${ }^{8}$ Sehubungan dengan hal tersebut, Philipus M. Hadjon menyatakan bahwa prinsip keabsahaan dalam Hukum Administrasi memiliki tiga fungsi yakni: ${ }^{9}$

a. Bagi aparat pemerintah, prinsip keabsahan berfungsi sebagai norma pemerintah (bestuurnorm);

b. Bagi masyarakat, prinsip keabsahan berfungsi sebagai perlindungan hukum serta alasan mengajukan gugatan terhadap segala tindakan pemerintah (beroepgeronden);

c. Bagi hakim, prinsip keabsahan berfungsi sebagai dasar pengujian suatu tindakan pemerintah (toetsinggronden). 
Apabila dalam penetapan KTUN sudah sesuai dengan peraturan perundangundangan yang berlaku, maka KTUN tersebut dianggap sah dan sebaliknya. Dalam hukum administrasi sendiri dimungkinkan adanya peninjauan kembali terhadap suatu KTUN yang telah dituangkan dalam Pasal 63 sampai dengan Pasal 66 UU Administrasi Pemerintahan. Dalam pasal tersebut dijelaskan mengenai adanya perubahan, pencabutan, penundaan serta pembatalan suatu Keputusan Tata Usaha Negara. Peninjauan kembali dapat dilakukan apabilan dalam aspek keabsahan KTUN tersebut telah terpenuhi dan segala tindakan pemerintahan sudah berdasarkan peraturan perundang-undangan yang berlaku, hal ini merupakan konsekuensi dari prinsip negara hukum. Philipus M. Hadjon juga menyatakan bahwa prinsip legalitas dalam segala tindakan atau keputusan pemerintahan meliputi aspek kewenangan, substansi dan prosedur. Di dalam UU Adminitrasi Pemerintahan, terdapat pembedaan mengenai pengertian wewenang dan kewenangan. Dalam Pasal 1 angka 5 UU Administrasi Pemerintahan dinyatakan bahwa wewenang adalah hak yang dimiliki oleh badan dan/atau pejabat pemerintahan atau penyelenggara negara lainnya untuk mengambil keputusan dan/atau tindakan dalam penyelenggaraan pemerintahan. Sementara di dalam Pasal 1 angka 6 UU Administrasi Pemerintahan dinyatakan bahwa kewenangan pemerintahan yang selanjutnya disebut kewenangan adalah kekuasaan badan dan/atau pejabat pemerintahan atau penyelenggara negara lainnya untuk bertindak dalam ranah hukum publik. Terkait dengan kewenangan, Philipus M. Hadjon berpendapat bahwa dalam Hukum Tata Negara wewenang (bevoegdheid) dideskripsikan sebagai kekuasaan hukum (rechtsmacht). Jadi dalam konsep hukum publik, wewenang berkaitan dengan kekuasaan.

Setiap penetapan KTUN harus didasarkan pada wewenang yang sah, sebagaimana ditentukan dalam Pasal 8 ayat 1 UU Administrasi Pemerintahan. Keputusan Tata Usaha Negara dapat dikatakan sah apabila dalam penetapan keputusan tersebut dilakukan oleh badan atau pejabat pemerintahan yang berwenang. Dalam tindakan yang dilakukan pemerintah terhadap kekeliruan atau tidak sahnya KTUN, terdapat asas contrarius actus sebagai acuan dalam melihat keabsahan dari suatu KTUN. Asas contrarius actus sendiri yakni, asas yang menyatakan bahwa 
badan atau pejabat pemerintahan yang menerbitkan KTUN dengan sendirinya juga berwenang untuk membatalkan. Apabila KTUN ditetapkan oleh badan atau pejabat pemerintah yang tidak berwenang, maka KTUN tersebut dapat dikatakan batal demi hukum (nietig van rechtwege) serta dapat dilakukannya perubahan, pencabutan, penundaan dan pembatalan suatu Keputusan Tata Usaha Negara. Akibat hukum yang timbul dari batal demi hukum tersebut, yaitu perbuatan yang sudah dilakukan dianggap tidak pernah ada atau tidak sah secara hukum.

Kewenangan dalam melakukan peninjauan kembali terhadap suatau Keputusan Tata Usaha Negara dituangkan dalam Pasal 63 sampai dengan Pasal 66 UU Administrasi Pemerintahan, dengan rincian sebagai berikut:

Perubahan terhadap suatu KTUN hanya dapat dilakukan oleh pejabat pemerintahan yang menetapkan surat keputusan tersebut, seperti yang dijelaskan pada Pasal 63 ayat (3), yakni: "Keputusan perubahan sebagaimana dimaksud pada ayat (1) hanya dapat ditetapkan oleh Pejabat Pemerintahan yang menetapkan surat keputusan dan berlaku sejak ditetapkannya Keputusan perubahan tersebut”.

Terhadap pencabutan suatu KTUN hanya dapat dilakukan oleh pejabat pemerintahan dan atasan pejabat serta dilakukan pencabutan atas perintah pengadilan seperti yang dijelaskan pada Pasal 64 ayat (3), yakni:

Keputusan pencabutan sebagaimana dimaksud pada ayat (2) dapat dilakukan:

a. Oleh pejabat pemerintahan yang menetapkan keputusan;

b. Oleh atasan pejabat yang menetapkan keputusan; atau

c. Atas perintah pengadilan.

Penundaan terhadap suatu KTUN hanya dapat dilakukan oleh pejabat pemerintahan yang menetapkan keputusan tersebut serta atasan pejabat, seperti yang dijelaskan pada Pasal 65 ayat (2), yakni:

Penundaan Keputusan sebagaimana dimaksud pada ayat (1) dapat dilakukan oleh:

a. Pejabat Pemerintahan yang menetapkan Keputusan; dan/atau

b. Atasan Pejabat.

Pembatalan terhadap suatu KTUN hanya dapat dilakukan oleh pejabat pemerintahan dan atasan pejabat serta dilakukan pencabutan atas perintah 
pengadilan, seperti yang dijelaskan pada Pasal 66 ayat (3), yakni:

Keputusan pembatalan sebagaimana dimaksud pada ayat (1) dapat dilakukan oleh:

a. Pejabat Pemerintahan yang menetapkan Keputusan;

b. Atasan Pejabat yang menetapkan Keputusan; atau

c. Atas putusan Pengadilan.

Dalam hal pencabutan izin reklamasi, Pemerintah Daerah (PEMDA) yang merupakan pejabat tata usaha negara yang mempunyai wewenang untuk melakukan tindakan hukum tata usaha negara dalam rangka menengakkan hukum administrasi selama dalam pencabutan izin reklamasi tersebut menjadi dasar kewenangan dari Pemerintah Daerah, terlebih dengan diberlakukannya asas contrarius actus. Izin reklamasi tersebut dapat mengalami peninjauan kembali yang berupa perubahan, pencabutan, penundaan dan pembatalan yang hanya dapat dilakukan oleh badan atau pejabat pemerintahan yang berwenang serta atas perintah pengadilan. Badan atau pejabat pemerintah dalam hal ini diberikan kekuasaan dalam segala tindakan pemerintahan secara atribusi, delegasi atau mandat. Menurut Philipus M. Hadjon, kekuasaan pemerintahan dibatasi secara substansi. Peraturan perundang-undangan menjadi dasar bagi pemerintah dalam melakukan tindakan pemerintahan, karena dalam peraturan perundang-undangan tersebut memuat wewenang badan atau pejabat pemerintahan yang menanganinya. Pemerintah Pusat maupun Pemerintah Daerah dapat melakukan peninjauan kembali suatu KTUN dengan melakukan perubahan, pencabutan, penundaan dan pembatalan KTUN tersebu seperti yang sudah diatur dalam UU Administrasi Pemerintahan. KTUN dapat dilakukan perubahan apabila terdapat kesalahan konsideran, redaksional, perubahan dasar pembuatan keputusan serta adanya fakta baru. Seperti yang dijelaskan pada Pasal 63 ayat 1 UU Administrasi, yakni:

Keputusan dapat dilakukan perubahan apabila terdapat:

a. Kesalahan konsideran;

b. Kesalahan redaksional;

c. Perubahan dasar pembuatan Keputusan; dan/atau

d. Fakta baru. 
KTUN dapat dilakukan pencabutan apabilan dalam penerbitan KTUN tersebut terdapat cacat wewenang, substansi serta prosedur sebagaimana yang dijelaskan dalam Pasal 64 ayat (1) UU Administrasi Pemerintahan, yakni:

Keputusan hanya dapat dilakukan pencabutan apabila terdapat cacat:

a. Wewenang;

b. Prosedur; dan/atau

c. Substansi.

Dapat ditundanya suatu pelaksanaan penetapan KTUN apabila berpotensi menimbulkan kerugian negara, kerusakan lingkungan hidup dan adanya konflik sosial, seperti yang dijelaskan dalam Pasal 65 ayat (1) UU Administrasi Pemerintahan, yakni:

Keputusan yang sudah ditetapkan tidak dapat ditunda pelaksanaannya, kecuali jika berpotensi menimbulkan:

a. Kerugian negara;

b. Kerusakan lingkungan hidup; dan/atau

c. Konflik sosial.

KTUN dapat dibatalkan apabila terdapat cacat wewenang, prosedur serta substansi, seperti yang dijelaskan dalam Pasal 66 ayat (1), yakni:

Keputusan hanya dapat dibatalkan apabila terdapat cacat:

a. Wewenang;

b. Prosedur; dan/atau

c. Substansi.

Dalam hal pencabutan izin reklamasi sebagai suatu Keputusan Tata Usaha Negara, apabila dalam mekanisme penerbitan izin reklamasi trsebut menyalahi peraturan perundang-undangan yang berlaku maka Pemerintah Pusat maupun Pemerintah Daerah yang menerbitkan KTUN tersebut dapat melakukan peninjauan kembali dengan bentuk perubahan, pencabutan, penundaan dan pembatalan KTUN. Menurut Philipus M. Hadjon, asas umum prosedur bertumpu atas tiga landasan utama hukum administrasi, yaitu prinsip negara hukum, prinsip demokrasi dan 
prinsip instrumental. ${ }^{10}$ Prinsip negara hukum dalam prosedur utamanya berkaitan dengan perlindungan terhadap hak-hak dasar manusia, seperti hak untuk tidak menyerahkan dokumen yang sifatnya rahasia. Prinsip demokrasi dalam prosedur berkenaan dengan prinsip keterbukaan (transparancy) dalam penyelenggaraan pemerintahan. Melalui keterbukaan ini maka memungkinkan msyarakat turut serta berperan dalam pengambilan keputusan. Sedangkan prinsip instrumental meliputi asas efisiensi (doelmatigheid/daya guna) dan asas efektivitas (doeltreffenheid/ hasil guna). Prosedur memiliki peranan yang sangat penting dalam penetapa Keputusan Tata Usaha Negara, selain berfungsi untuk mewujudkan legitimasi serta transparansi, prosedur berfungsi untuk tanggung jawab perlindungan terhadap hak dan kepentingan masyarakat terhadap penetapan KTUN tersebut. Seperti halnya tindakan pemerintah dalam melakukan perubahan, pencabutan, dan pembatalan suatu Keputusan Tata Usaha Negara, hendaknya kembali menetapkan suatu keputusan perubahan, keputusan pencabautan dan keputusan pembatalan.

Dalam rangka tugas mengatur dan hubungan hukum antara Pemerintah Pusat maupun Pemerintah Daerah dengan masyarakat, maka dibentuklah izin yang merupakan suatu persetujuan dari pemerintah berdasarkan peraturan perundangundangan untuk menyimpang dari ketentuan larangan peraturan perundangundangan tersebut. ${ }^{11}$ Berdasarkan pengertian izin tersebut, tujuan dari izin sendiri yakni sebagai instrumen dalam mengendalikan aktivitas masyarakat dengan cara mempengaruhi para warga agar mau mengikuti cara-cara yang dianjurkan guna mencapai suatu tujuan. ${ }^{12}$ Izin juga merupakan suatu penetapan yang merupakan dispensasi daripada suatu larangan undang-undang. Pada umumnya pasal undangundang bersangkutan berbunyi dilarang tanpa izin, melakukan dan seterusnya. larangan tersebut diikuti dengan perincian dari syarat-syarat yang disertai penetapan prosedur serta petunjuk pelaksana, kriteria, dan sebagainya yang perlu dipenuhi

\footnotetext{
${ }^{10}$ Philipus M Hadjon, Op.Cit.[22].

11 Tatiek Sri Djatmiati et al, Buku Ajar Hukum Perizinan (Fakultas Hukum Universitas Airlangga 2012).[1].

${ }^{12}$ ibid. [2].
} 
oleh pemohon untuk memperoleh dispensasi dari larangan tersebut, disertai dengan penetapan prosedur dan petunjuk pelaksana.

Dalam tahapan penyelenggaraan perolehan hak atas tanah melalui reklamasi adanya tahapan perolehan izin lokasi serta pemilikan Izin Mendirikan Bangunan (IMB). Menurut Pasal 1 angka 1 Peraturan Menteri Agraria dan Tata Ruang Nomor 5 Tahun 2015 tentang Izin Lokasi pengertian izin lokasi adalah izin yang diberikan kepada perusahaan untuk memperoleh tanah yang diperlukan dalam rangka penanaman modal yang berlaku pula sebagai izin pemindahan hak, dan untuk menggunakan tanah tersebut guna keperluan usaha penanaman modalnya. Dalam permohonan izin lokasi dicantumkan luas tanah yang diperlukan oleh perusahaan swasta untuk suatu proyek pembangunan yang bersifat komersial. Jangka waktu pemberian izin lokasi dibedakan berdasarkan besarnya luas tanah yang diberikan dalam izin lokasi tersebut. Sedangkan, Pemerintah Daerah kepada subyek hukum untuk mengatur, mengawasi, serta memperbaiki, merombak/ merobohkan bangunan agar desain pelaksaan pembangunan sesuai dengan tata ruang yang berlaku. Tujuan diperlukannya IMB adalah untuk menjaga ketertiban, keselarasan, kenyamanan dari bangunan itu sendiri terhadap penghuninya maupun lingkungan sekitarnya.

Sistem izin sendiri terdiri atas larangan dengan persetujuan yang menjadi dasar dengan ketentuan-ketentuan yang berhubungan dengan izin tersebut. Dalam penegakan hukum administrasi, pencabutan izin merupakan salah satu instrumen yuridis sarana hukum administrasi. Akan tetapi dalam pelaksanaannya, tidak semua pencabutan izin atau pengubahan izin merupakan sanksi yang harus diterapkan terhadap pelanggaran hukum. Dalam menerapkan sanksi administrasi pada dasarnya merupakan suatu wewenang bebas, oleh karena itu pemerintah diberi wewenang untuk mempertimbangkan atau menilai untuk menggunakan wewenang tersebut serta didasarkan pada norma pemerintahan, baik tertulis maupun tidak tertulis. Izin pelaksanaan reklamasi dapat dicabut apabila, seperti yang sudah dituangkan dalam Pasal 20 ayat 1 Peraturan Presiden Nomor 122 Tahun 2012 tentang Reklamasi di Wilayah Pesisir dan Pulau-Pulau Kecil, yakni: 
a. Tidak sesuai dengan perencanaan reklamasi; dan/atau

b. Izin lingkungan dicabut.

Segala tindakan pengembang ataupun pelaku usaha yang tidak menjalankan kewajibannya serta tindakan penyalahgunaan yang sewenang-wenang, maka tindakan yang dilakukan oleh pelaku usaha tersebut adalah cacat substansial. Cacat substansi sendiri seperti yang telah diatur dalam Penjelasan Pasal 64 ayat 1 huruf c UU Administrasi Pemerintahan, yakni:

1. Keputusan tidak dilaksanakan oleh penerima Keputusan sampai batas waktu yang ditentukan;

2. Fakta-fakta dan syarat-syarat hukum yang menjadi dasar Keputusan telah berubah;

3. Keputusan dapat membahayakan dan merugikan kepentingan umum; atau

4. Keputusan tidak digunakan sesuai dengan tujuan yang tercantum dalam isi Keputusan.

Dalam penerbitan ataupun pencabutan KTUN, unsur substansi mewajibkan pemerintah dalam menetapkan ataupun melakukan pencabutan terhadap suatu KTUN harus berdasarkan pada AUPB. Hal tersebut sebagaimana ditentukan dalam Pasal 8 ayat 2 huruf b UU Administrasi Pemerintahan, yakni: Badan dan/atau Pejabat Pemerintahan dalam menggunakan Wewenang wajib berdasarkan:

a. Peraturan perundang-undangan; dan

b. AUPB.

Menurut Philipus M. Hadjon, AUPB harus dipandang sebagai norma hukum yang tidak tertulis yang senantiasa harus ditaati oleh pemerintah. ${ }^{13}$ AUPB dimaksudkan sebagai sarana perlindungan hukum (rechtsbescherming) dan bahkan dijadikan sebagai instrument untuk peningkatan perlindungan hukum (verhoogde rechtsbescherming) bagi warga negara terlebih bagi para pengembang ataupun pelaku usaha dari tindakan pemerintah. AUPB sendiri sudah tertulis dalam Pasal 10 ayat 1 UU Administrasi Pemerintahan, yaitu:

AUPB yang dimaksud dalam Undang-Undang ini meliputi asas:

a. Kepastian hukum;

${ }^{13}$ Philipus M. Hadjon, et.al., Pengantar Hukum Administrasi di Indonesia (Gadjah Mada University Press Yogyakarta 2002).[370]. 
b. Kemanfaatan;

c. Ketidakberpihakan;

d. Kecermatan;

e. Tidak menyalahgunakan kewenangan;

f. Keterbukaan;

g. Kepentingan umum; dan

h. Pelayanan yang baik.

AUPB selanjutnya dijadikan dasar penilaian dalam peradilan dan upaya administrasi. Sehingga pada dasarnya, AUPB memiliki dua fungsi yakni sebagai dasar penilaian bagi hakim dan sebagai norma pengarah bagi segala tindakantindakan pemerintah. Asas-asas Umum Pemerintahan Yang Baik (AUPB) merupakan bentuk norma pemerintahan yang tidak tertulis. Dengan demikian pelaksanaan AUPB memiliki beberapa fungsi yang meliputi: ${ }^{14}$

1. Sebagai norma hukum bagi pemerintah dalam menetapkan izin atau keputusan sanksi administrasi;

2. Sebagai norma pembanding dan perlindungan bagi pihak yang dirugikan atas ditetapkannya izin atau keputusan sanksi administrasi;

3. Sebagai norma pengujian bagi hakim dalam memeriksa izin atau keputusan sanksi administrasi yang menjadi objek sengketa.

Penataan ruang yang didasarkan pada karakteristik, daya dukung dan daya tampung lingkungan serta didukung oleh teknologi yang sesuai akan meningkatkan kualitas ruang yang ada. ${ }^{15}$ Pelaksanaan pembangunan yang dilaksanakan baik oleh Pemerintah, Pemerintah Daerah maupun masyarakat baik pada tingkat pusat maupun pada tingkat daerah, harus dilakukan sesuai dengan rencana tata ruang yang telah ditetapkan. Berdasarkan Pasal 2 Undang-Undang Nomor 26 Tahun 2007 tentang Penataan Ruang menetapkan bahwa dalam kerangka Negara Kesatuan Republik Indonesia, penataan ruang diselenggarakan berdasarkan asas penataan ruang. Dalam kasus Reklamasi Teluk Jakarta, Pemerintah Daerah dalam hal ini Gubernur DKI Jakarta sebagai pihak yang berwenang dalam melakukan pencabutan izin reklamasi mengeluarkan suatu Keputusan Gubernur DKI Jakarta

\footnotetext{
${ }^{14}$ Tatiek Sri Djatmiati et al, Op.Cit.[65].

${ }^{15}$ Urip Santoso, Op.Cit.[10].
} 
Nomor 1409 Tahun 2018 tentang Pencabutan Beberapa Keputusan Gubernur Tentang Pemeberian Izin Pelaksanaan Reklamasi. Dalam isi Keputusan tersebut berisi pencabutan dan tidak berlakunya lagi Keputusan Gubernur tentang Pemberian Izin Pelaksanaan beberapa pulau reklamasi. Hal tersebut sudah sesuai dengan asas contrarius actus. Selain itu alasan dicabut izin reklamasi tersebut adanya pertimbangan hukum seperti yang dijelaskan dalam Penjelasan Pasal 64 ayat 1 huruf c UU Administrasi Pemerintahan, yakni:

1. Keputusan tidak dilaksanakan oleh penerima Keputusan sampai batas waktu yang ditentukan;

2. Fakta-fakta dan syarat-syarat hukum yang menjadi dasar Keputusan telah berubah.

Pelaku usaha ataupun pengembang dalam hal ini tidak menjalankan kewajibannya untuk melakukan pembangunan di pulau reklamasi sebagaimana batas waktu yang telah ditetapkan, maka Gubernur DKI Jakarta berwenang melakukan pencabutan izin pulau reklamasi tersebut. Sedangkan apabila berdasarkan asas hukum penataan ruang, parameter yang dapat dijadikan Pemerintah Daerah dalam pencabutan izin reklamasi tersebut yakni, asas keberlanjutan dan perlindungan kepentingan umum. Dengan adanya pulau reklamasi dampat negatif yang dapat merugikan kelestarian dan kelangsungan lingkungan sekitar pulau reklamasi perlu diperhatikan untuk kepentingan generasi mendatang. Serta perlunya asas kepentingan umum demi kesejahteraan masyarakat sekitar pulau reklamasi.

\section{Upaya Perlindungan Hukum yang Dapat Dilakukan Oleh Pelaku Usaha Terhadap Pencabutan Izin Reklamasi}

Terdapat dua jalur atau dua jalur atau dua alur berperkara di muka Peradilan Tata Usaha Negara. Bagi KTUN yang tidak mengenal adanya upaya administratif, gugatan ditujukan kepada PTUN (tingkat pertama) sedangkan bagi KTUN yang mengenal adanya upaya administratif gugatan langsung ditujukan kepada Pengadilan 
Tinggi Tata Usaha Negara. ${ }^{16}$ Ketentuan tersebut berdasarkan Pasal 51 ayat (3) UU PTUN yang menyatakan bahwa: "Pengadilan Tinggi Tata Usaha Negara bertugas dan berwenang memeriksa, memutus, dan menyelesaikan di tingkat pertama sengketa Tata Usaha Negara sebagaimana dimaksud dalam Pasal 48". Artinya apabila KTUN memungkinkan atau menyediakan upaya administratif maka gugatan langsung diajukan kepada Pengadilan Tinggi Tata Usaha Negara, sedangkan apabila KTUN tidak memungkinkan atau tidak menyediakan upaya administratif maka gugatan diajukan kepada Pengadilan Tata Usaha Negara. ${ }^{17}$ Berbeda seperti yang diatur dalam UU Administrasi Pemerintahan seperti yang dijelaskan dalam Pasal 75 ayat (1), yakni: "Warga Masyarakat yang dirugikan terhadap Keputusan dan/atau Tindakan dapat mengajukan Upaya Administratif kepada Pejabat Pemerintahan atau Atasan Pejabat yang menetapkan dan/atau melakukan Keputusan dan/atau Tindakan.” Dalam pasal tersebut upaya administratif dapat diajukan tanpa harus terlebih dahulu mempersengketakan KTUN tersebut ke Pengadilan Tata Usaha Negara. Kemudian dalam Pasal 1 angka (16) UU Administrasi Pemerintahan, dijelaskan mengenai pengertian upaya administratif yang merupakan proses penyelesaian sengketa yang dilakukan dalam lingkungan Administrasi Pemerintahan sebagai akibat dikeluarkannya keputusan dan/atau tindakan yang merugikan.

Ada dua macam upaya administratif, yitu banding admnistrasi dan keberatan. ${ }^{18}$ Kedua macam upaya administratif tersebut merupakan dua prosedur yang harus dibedakan. Keberatan sendiri merupakan upaya administrasi yang diberikan kepada pemohon keputusan atau masyarakat untuk melakukan penyelesaian permasalahan pada instansi atau badan yang sama. Dalam penyelesaian sengketa tata usaha negara dapat dilakukan sendiri oleh Badan atau Pejabat Tata Usaha Negara yang mengeluarkan Keputusan Tata Usaha Negara. Keberatan merupakan prosedur dalam upaya administrasi yang dilakukan sebelum diterbitkannya suatu KTUN atau Izin.

\footnotetext{
${ }^{16}$ Philipus M. Hadjon, et.al., Op.Cit.[317].

${ }^{17}$ Hari Sugiharto dan Bagus Oktafian Abrianto, 'Upaya Administratif Sebagai Perlindungan Hukum Bagi Rakyat dalam Sengketa Tata Usaha Negara’ (2018) 11 No 1 Arena Hukum.[151].

${ }^{18}$ Philipus M. Hadjon, et.al., Op.Cit.[317].
} 
Sedangkan pengertian banding sendiri dijelaskan dalam Penjelasan Pasal 75 ayat 2 UU Administrasi Pemerintahan yakni:"Yang dimaksud dengan "banding" adalah banding administratif yang dilakukan pada atasan Atasan Pejabat yang menetapkan Keputusan konstitutif". Banding administratif sendiri merupakan prosedur dalam upaya administratif yang melakukan perlindungan hukum terhadap diterbitkannya izin yang dalam penyelesaian sengketa tata usaha negara yang dilakukan oleh instansi atasan atau instansi lain dari Badan/Pejabat Tata Usaha Negara yang mengeluarkan Keputusan Tata Usaha Negara, yang berwenang memeriksa ulang Keputusan Tata Usaha Negara yang disengketakan. ${ }^{19}$ Berbeda dengan prosedur di Peradilan Tata Usaha Negara, pada prosedur banding administratif atau prosedur keberatan dilakukan penilaian yang lengkap, baik dari segi penerapan hukum maupun dari segi kebijaksanaan oleh instansi yang memutus. ${ }^{20}$ Peraturan perundangundangan menjadi dasar dari dikeluarkannya Keputusan Tata Usaha Negara yang bersangkutan untuk dapat dilihat apakah suatu Keputusan Tata Usaha Negara tersebut dapat ditempuh dengan upaya administratif. Perbedaan antara UU PTUN dengan UU Administrasi Pemerintahan terkait pengertian upaya administrasi jika berdasarkan asas lex specialis derogat legi generali, hendaknya menerapkan ketentuan upaya administratif yang sudah diatur dalam undang-undang sektoral, yakni sebelum masyarakat mengajukan gugatan ke Pengadilan Tata Usaha Negara harus melakukan upaya administratif yang tersedia (keberatan dan/atau banding administratif). ${ }^{21}$

Dalam praktik peradilan sesuai dengan Surat Edaran Mahkamah Agung Nomor 4 Tahun 2016 tentang Pemberlakuan Rumusan Hasil Rapat Pleno Kamar Mahkamah Agung Tahun 2016 Sebagai Pedoman Pelaksanaan Tugas Bagi Pengadilan (selanjutnya disebut SEMA4/2016) point E mengenai Rumusan Hukum Kamar Tata Usaha Negara, angka 1, huruf c. Menentukan bahwa perubahan beracara di Peradilan Tata Usaha Negara pasca berlakunya UU Administrasi Pemerintahan

\footnotetext{
${ }^{19}$ ibid.

${ }^{20}$ ibid.

${ }^{21}$ Hari Sugiharto dan Bagus Oktafian Abrianto, Op.Cit.[158].
} 
menyatakan bahwa: "Keputusan Tata Usaha Negara yang sudah diperiksa dan diputus melalui upaya banding administrasi menjadi kewenangan Pengadilan Tata Usaha Negara”. Pasca berlakunya SEMA 4/2016 tersebut, Pengadilan Tata Usaha Negara berwenang sebagai pengadilan tingkat pertama yang memeriksa, memutus dan mengadili sengketa tata usaha negara setelah upaya banding administratif dilakukan oleh masyarakat. ${ }^{22}$

Peradilan Tata Usaha Negara di Indonesia dimulai dengan lahirnya UndangUndang Nomor 5 Tahun 1986 tentang Peradilan Tata Usaha Negara sebagaimana telah diubah dengan Undang-Undang Nomor 9 Tahun 2004 dan Undang-Undang Nomor 51 Tahun 2009. Pasal 47 UU PTUN sendiri mengatur tentang kewenangan dari Peradilan Tata Usaha Negara dalam sistem peradilan di Indonesia, yakni bertugas dan berwenang memeriksa, memutus, dan menyelesaikan sengketa tata usaha negara. Kedudukan Peradilan Tata Usaha Negara sendiri sama dengan peradilan lainnya dalam pelaksanaan kekuasaan kehakiman. Seperti yang dituliskan dalam Pasal 4 UU PTUN yang menyebutkan bahwa Peradilan Tata Usaha Negara adalah salah satu pelaksanaan kekuasaan kehakiman bagi rakyat pencari keadilan terhadap sengketa tata usaha Negara. Pengadilan Tata Usaha Negara sendiri mempunyai kewenangan menyelesaikan sengketa tata usaha negara di tingkat pertama, untuk tingkat banding diselesaikan di Pengadilan Tinggi Tata Usaha Negara serta tingkat kasasi diselesaikan di Mahkamah Agung. Dalam beracara di Peradilan Tata Usaha Negara yakni adanya orang atau badan hukum yang kepentingannya merasa dirugikan oleh keputusan badan atau pejebata tata usaha negara. Adanya unsur kepentingan ini dapat dilihat dalam Pasal 53 ayat (1) Undang-Undang Nomor 9 Tahun 2004 tentang perubahan atas Undang-Undang Nomor 5 Tahun 1968, yang berbunyi: "Orang atau badan hukum perdata yang merasa kepentingannya dirugikan oleh suatu Keputusan tata usaha Negara dapat mengajukan gugatan tertulis kepada pengadilan yang berwenang yang berisi tuntutan agar Keputusan tata usaha Negara yang disengketakan itu dinyatakan batal atau tidak sah, dengan atau tanpa disertai

${ }^{22}$ ibid.[159]. 
tuntutan ganti rugi dan atau rehabilitasi”. Tahapan-tahapan penyelesaian sengketa tata usaha negara dalam Peradilan Tata Usaha Negara berdasarkan Pasal 53 ayat (1) UU PTUN menyebutkan bahwa seorang atau badan hukum perdata yang merasa kepentingannya dirugikan oleh suatu keputusan Tata Usaha Negara dapat mengajukan gugatan tertulis kepada pengadilan yang berwenang, berisi tuntutan agar keputusan Tata Usaha Negara yang disengketakan dinyatakan batal atau tidak sah, dengan atau tanpa disertai tuntutan ganti rugi dan/atau rehabilitasi. Adanya tenggang waktu gugat adalah batas waktu seperti yang dijelaskan dalam undangundang, seseorang atau badan hukum perdata yang measa dirugikan terhadap penatapan KTUN dapat memperjuangkan haknya dengan mengajukan gugatan melalui Pengadilan Tata Usaha Negara. Dengan demikian apabila tenggang waktu tersebut tidak dipergunakan maka kesempetan dalam mengajukan gugatan tersebut menjadi hilang dan gugatannya dinyatakan tidak dapat diterima. Pengajuan gugatan sengketa tata usaha negara tidak dapat dilakukan sebelum atau setelah lewat tenggang waktu yang ditentukan dalam peraturan perundang-undangan. Dasar hukum tenggang waktu gugat diatur dalam Pasal 55 Undang-Undang Nomor 9 Tahun 2004 tentang perubahan atas UndangUndang Nomor 5 Tahun 1986, yang berbunyi: "Gugatan hanya dapat diajukan dalam tenggang waktu sembilan puluh hari terhitung sejak saat diterimanya atau diumumkannya Keputusan badan atau pejabat tata usaha negara". Selain pengajuan gugatan sesuai dengan tenggang waktu 90 (sembilan puluh) hari. Proses dismissal atau rapat permusyawaratan ini dilakukan setelah mengajukan gugatan. Berdasarkan pasal 62 UU PTUN, dalam rapat permusyawaratan, pengadilan berwenang untuk menetapkan bahwa gugatan yang diajukan itu dinyatakan tidak diterima atau tidak berdasar. Berdasarkan Pasal 63 Undang-Undang Nomor 9 Tahun 2004 Tentang perubahan atas Undang-Undang Nomor 5 Tahun 1986 Tentang Peradilan Tata Usaha Negara disebutkan bahwa:

(1)Sebelum pemeriksaan pokok sengketa dimulai, hakim wajib mengadakan pemeriksaan persiapan untuk melengkapi gugatan yang kurang jelas;

(2)Dalam pemeriksaan persiapan sebagaimana dimaksud dalam ayat (1) hakim:

a. Wajib memberi nasihat kepada penggugat untuk memperbaiki gugatan 
dan melengkapinya dengan data yang diperlukan dalam jangka waktu tiga puluh hari.

b. Dapat meminta penjelasan kepada badan atau pejabat tata usaha Negara yang bersangkutan.

(3)Apabila dalam jangka waktu sebagaimana dimaksud dalam ayat (2) huruf a penggugat belum menyempurnakan gugatan, maka hakim menyatakan dengan putusan gugatan tidak dapat diterima.

(4)Terhadap putusan sebagaimana dimaksud dalam ayat (3) tidak dapat digunakan upaya hukum tetapi dapat diajukan gugatan baru.

Dalam penjelasannya disebutkan bahwa ketentuan ini merupakan kekhususan dalam proses pemeriksaan sengketa tata usaha negara. Kepada hakim diberikan kemungkinan untuk mengadakan pemeriksaan persiapan sebelum memeriksa pokok sengketa. Berdasarkan penjelasan tersebut maka, tahap pemeriksaan persiapan adalah merupakan wewenang dari hakim yang telah ditunjuk oleh Ketua PTUN dalam bentuk majelis hakim untuk melakukan pemeriksaan lanjutan atas perkarayang telah dinyatakan lolos dismissal. Dimana dalam pemeriksaan ini hakim dapat meminta kepada penggugat untuk memperbaiki gugatannya dan melengkapinya dengan data-data yang diperlukan dalam jangka waktu tertentu yakni 30 (tiga puluh) hari. Apabila ada pihak yang merasa dirugikan dengan putusan tersebut, dapat mengajukan banding ke Pengadilan Tinggi Tata Usaha Negara yang berwenang memeriksa dan memutus sengketa Tata Usaha Negara. Banding juga disebut dengan istilah "ulangan pemeriksaan" yang berasal dari bahasa latin apellare. ${ }^{23}$ Arti banding, yaitu pemeriksaan dalam instansi (tingkat) kedua oleh sebuah pengadilan atasan yang mengulangi seluruh pemeriksaan, baik yang mengenai fakta-faktanya, maupun penerapan hukum atau undang-undang. ${ }^{24}$ Bahkan jika penggugat tidak juga puas dengan putusan tersebut, dapat dilakukan upaya hukum kasasi hingga upaya hukum luar biasa peninjauan kembali kepada Mahkamah Agung. Sebagaimana yang telah dituangkan dalam Pasal 131 ayat 1 UU

\footnotetext{
${ }^{23}$ Philipus M. Hadjon, et.al., Op.Cit.[362].
}

${ }^{24}$ ibid. 
PTUN, yakni "Terhadap putusan tingkat terakhir Pengadilan dapat dimohonkan pemeriksaan kasasi kepada Mahkamah Agung”. Dan Pasal 132 ayat (1) UU PTUN, yakni "Terhadap putusan Pengadilan yang telah memperoleh kekuatan hukum tetap dapat diajukan permohonan peninjauan kembali kepada Mahkamah Agung". Bagi pelaku usaha ataupun pengembang apabila merasa dirugikan terkait pencabutan izin Reklamasi Teluk Jakarta tersebut dengan mengajukan upaya administratif ataupun dapat mengajukan gugatan ke Pengadilan Tata Usaha Negara Jakarta. Apabila tidak puas dengan keputusan PTUN tersebut, pelaku usaha ataupun pengembang dapat mengajukan banding di Pengadilan Tinggi Tata Usaha Negara dan bahkan mengajukan kasasi kepada Mahkamah Agung.

\section{Kesimpulan}

Segala tindakan yang dilakukan Pemerintah Pusat maupun Pemerintah Daerah dalam penetapan izin reklamasi sebagai suatu Keputusan Tata Usaha Negara dilakukan secara sepihak, namun sesuai Pasal 5 dan Pasal 8 ayat 2 UU Administrasi Pemerintahan dalam penetapan suatu KTUN harus berdasarkan peraturan perundangundangan dan AUPB dengan berlandaskan asas kepastian hukum dan asas kecermatan. Suatu keputusan dapat dilakukan pencabutan apabila terdapat adanya cacat wewenang, cacat prosedur dan cacat substansi seperti yang dijelaskan dalam Pasal 64 ayat 1 UU Administrasi Pemerintahan. Salah satu alasan adanya cacat substansi dalam pencabutan izin reklamasi ini yakni, pelaku usaha ataupun pengembang tidak menjalankan kewajibannya untuk melakukan pembangunan di pulau reklamasi sebagaimana batas waktu yang telah ditetapkan. Perlindungan hukum dengan cara melakukan pengujian terhadap penetapan keputusan tersebut dapat dilakukan melalui upaya administratif dan melalui peradilan tata usaha negara. Upaya administratif yang tersedia dengan mengajukan keberatan dan/atau banding administratif, sedangkan Peradilan Tata Usaha Negara dengan mengajukan gugatan, prosedur dismissal dan pemeriksaan persiapan. Apabila ada pihak yang merasa dirugikan dengan putusan tersebut, dapat mengajukan banding ke Pengadilan Tinggi Tata Usaha Negara, bahkan dapat dilakukan upaya hukum kasasi kepada Mahkamah Agung. 


\section{Daftar Bacaan}

\section{Buku}

Erwin, Hukum Lingkungan (Refika Aditama 2008).

Philipus M. Hadjon et.all., Pengantar Hukum Administrasi di Indonesia (Gadjah Mada University Press 2002).

R. Wiyono, Hukum Acara Peradilan Tata Usaha Negara (Sinar Grafika 2008).

Tatiek Sri Djatmiati et.all., Buku Ajar Hukum Perizinan (Fakultas Hukum Universitas Airlangga 2012).

Urip Santoso, Hukum Penataan Ruang (Airlangga University Press 2012).

\section{Jurnal}

Antik Bintari dan Talolo Muara, 'Manajemen Konflik Penyelesaian Kasus Reklamasi Pulau G Pantai Utara Jakarta' (2018) 41 Jurnal Ilmu Pemerintah.

Hari Sugiharto dan Bagus Oktafian Abrianto, 'Upaya Administratif Sebagai Perlindungan Hukum Bagi Rakyat dalam Sengketa Tata Usaha Negara' (2018) 111 Arena Hukum.

Herman dan Hendry Julian Noor, 'Doktrin Tindakan Hukum Administrasi Negara Membuat Keputusan (Beschikking)' (2017) 31 Jurnal Komunikasi Hukum.

\section{Laman}

'Anies Baswedan Resmi Cabut Izin Reklamasi Teluk Jakarta', $<$ https://metro. tempo.co/read/1130345/anies-baswedan-resmi-cabut-izin- re kla mas i teluk-jakarta/full\&view=ok>, dikunjungi pada 14 Oktober 2019.

$<$ http://repository.uin-suska.ac.id/7052/4/BAB\%203.pdf $>$, dikunjungi pada 18 November 2019.

\section{Perundang-undangan}

Undang-Undang Dasar Negara Republik Indonesia 1945.

Undang-Undang Nomor 5 Tahun 1986 tentang Peradilan Tata Usaha Negara yang dirubah dengan Undang-Undang Nomor 9 Tahun 2004 dan Undang-Undang Nomor 51 Tahun 2009. 
Undang-Undang Nomor 26 Tahun 2007 tentang Penataan Ruang.

Undang-Undang Nomor 1 Tahun 2014 tentang Pengelolaan Wilayah Pesisir dan Pulau-pulau Kecil.

Undang-Undang Nomor 30 Tahun 2014 tentang Administrasi Pemerintahan.

Peraturan Pemerintah Nomor 16 Tahun 2004 tentang Penatagunaan Tanah.

Peraturan Presiden Nomor 122 Tahun 2012 tentang Reklamasi di Wilayah Pesisir dan Pulau-Pulau Kecil.

Keputusan Presiden Nomor 52 Tahun 1995 tentang Reklamasi Pantai Utara Jakarta.

Peraturan Menteri Agraria dan Tata Ruang Nomor 5 Tahun 2015 tentang Izin Lokasi.

Keputusan Gubernur Nomor 2268 Tahun 2015 tentang Pemberian Izin

Pelaksanaan Reklamasi Pulau F Kepada PT. Jakarta Propertindo.

Keputusan Gubernur Nomor 2637 Tahun 2015 tentang Pemberian Izin

Pelaksanaan Reklamasi Pulau H Kepada PT. Taman Harapan Indah.

Keputusan Gubernur Nomor 2269 Tahun tentang Pemberian Izin Pelaksanaan Reklamasi Pulau I Kepada PT. Jaladri Kertika Pakci.

Keputusan Gubernur DKI Jakarta Nomor 1409 Tahun 2018 tentang Pencabutan Beberapa Keputusan Gubernur Tentang Pemberian Izin Pelaksanaan Reklamasi.

Surat Edaran Mahkamah Agung Nomor 2 Tahun 1991 tentang Petunjuk Pelaksanaan Beberapa Ketentuan dalam Undang-Undang Nomor 5 Tahun 1986 Tentang Peradilan Tata Usaha Negara. 
Inigo Putera: Perlindungan Hukum Bagi...

--halaman ini sengaja dibiarkan kosong-- 